\title{
Impact of Downsizing on Employee Attitude and Performance: A Case Study of HBL
}

\author{
Bushra Akbar Khan \\ Dr. Farooq-e-Azam Cheema
}

\begin{abstract}
The function of downsizing today has become a byword for layoffs amidst burgeoning company, mergers and acquisitions and more particularly amid business devouring world wide recession. In the modern day world, where efficiency and effectiveness are imperative for survival, it is getting mandatory for the corporations of every kind to reduce their costs and improve their profitability by inducing modern cost cutting techniques-Human Resource traditionally being the first target. The banking industry in Pakistan has undergone similar restructuring, involving large scale layoffs in many local and multinational banks in the last few years. This study has attempted to investigate the factors which made downsizing a relevant strategy for the management in the Habib Bank Ltd, simultaneously identifying its employees' attitude and performance attitude in terms of job security, morale, turn over rate, absenteeism, degree of organizational citizenship, commitment towards long-term goals and projects. The study has been carried out among HBL employees at head office, Karachi through in depth interviews with Human Resource personnel involved in downsizing decisions. In the second stage an analysis of about 100-150 employees from the middle and lower management level belonging to departments which were most downsized was done. The study has explored the reasons for which an organization uses downsizing as a corporate policy, its impact on employee performance and investigate the various negative impacts of downsizing on the survivors' attitude in terms of job security, morale, turn over rate, absenteeism, degree of organizational citizenship, commitment towards long term goals and projects in the banking sector in general and Habib Bank Ltd in particular. The conclusions developed through this study will be useful in developing a set of guidelines on how the banking industry in Pakistan can effectively implement layoff strategies while maintaining employee performance, organizational citizenship and commitment among the survivors.
\end{abstract}

Keywords: Corporate downsizing, employee attitude, employee performance, organizational citizenship

\section{Introduction}

\subsection{Background of the Study}

Downsizing has become one of the most talked about phenomena in the last few years. With economies around the world faltering, companies being shut down, operations being halted and budgets being cut, employees all over the globe are being laid off. In

Bushra Akbar Khan is an adjunct faculty member at IBA and an MS student at SZABIST, akbarkhan14@hotmail.com

Dr Farooq Cheema is Assistant Professor at SZABIST, Karachi.

Journal of Independent Studies and Research - MSSE

Volume $8 \quad$ Number 1 January 2010 157 
the modern world, where competition does not permit organizations to work without efficiency and effectiveness, it has become pertinent for corporations of every kind to reduce their costs and improve their profitability by inducing modern cost cutting techniques, irrespective of whether the organizations are public or private or of any other kind.

The banking industry in Pakistan has undergone many structural changes, including large-scale layoff in many local and multinational banks in the last few years. Habib Bank is a leader in Pakistan's services industry. An extensive network of 1425 domestic branches-the largest in Pakistan-and 55 international branches has enabled HBL to provide comprehensive services that meet customer needs. Today, HBL plays a central role in Pakistan's financial and economic development. Habib Bank has been a pioneer in providing innovative banking services. These have included the installation of the first mainframe computer in Pakistan followed by the first ATM and more recently, internet banking facilities in all our 1425 domestic branches. The Bank's towering presence in Pakistan's financial and commercial life has remained unchanged over the decades. However since its privatization in 1997, HBL has undertaken several restructuring strategies in order to improve its efficiency and performance amidst cut throat competition in the ever increasing competition in the Pakistani Banking industry. The Habib Bank Limited has retrenched over 23000 employees in its downsizing process.

This study plans to focus on the factors which make downsizing a relevant strategy for the management and plans to investigate the issues related to downsizing on the organization as a whole as well as on the employee's performance. The study has tried to investigate the reasons for which an organization uses downsizing as a corporate policy, its impact on employee performance and attitude in the banking sector in general and Habib Bank Ltd. in particular.

\subsection{Research Problem}

HBL has undergone various structural changes since its privatization in 1997. An important part of the restructuring policy was downsizing $\mathrm{HBL}$ adopted downsizing as a corporate policy to reduce cost and improve employee performance. In 2006, downsizing at HBL was carried out on a large scale which resulted in layoffs of around 12,000 employees. Clerical and non-clerical staffs were the most hit segment. This was followed by downsizing at officers (lower management) and executives (upper management) levels. This research study has investigated firstly the effects of downsizing on the organization performance as a whole and then its impact on the survivors of the Habib Bank Limited. The positive and negative impacts of staff reduction on the performance and attitude of the employees has been studied across the middle and lower management hierarchy.

\subsection{Research Objectives}

The study undertaken plans to investigate the following: 
1. To identify various factors which led to downsizing being used as a corporate strategy.

2. To investigate various negative impacts of downsizing on the survivors' attitude in terms of job security, morale, turn over rate, absenteeism, degree of organizational citizenship, commitment towards long-term goals and projects.

3. To identify the most important attitude changes among the survivors which in turn has affected the organizations performance as a whole.

\subsection{Significance of the Study}

This report has investigated the reasons for selecting downsizing as a cost cutting strategy and its impact on survivors. The results show difference in employee attitude across hierarchy levels and an overall decreased organizational commitment and morale. The implications from the analysis and suggestions based on the research will definitely provide guidelines to all organizations in general, and banking sector in particular. Recent economic crisis has resulted in layoffs in many local and multinational organizations. Hence the comprehension of the trade off between costs and reduced commitment and need of open communication in case of implementing downsizing recommended in this study will be of great help to all such organizations.

\subsection{Research Methodology}

The researcher used descriptive method of research. This is a qualitative research and in-depth interviews and questionnaire were used as primary empirical data collection methods in this study. This research is based on employees of Habib Bank Limited. The research is particularly based on employees who are working in HBL head office. The sample comprised of two stages. The first stage consisted of 3 in-depth interviews from senior managers in HR. The second stage consisted of distribution of questionnaires among 200 employees from the middle and lower management level. Hence a list of senior and middle management employees from the HR department of Habib Bank head office was used as a sampling frame. For interviews convenience sampling was used depending on the willingness and response of the HR management. The sample for survey was selected through Proportionate Stratified Sampling. The final sample size obtained from the population of the two management stratas of HBL was 165 , of which 15 were from middle and 173 from lower management.

\section{Literature Review}

Kozlowsky, Chao, Smith and Hedlund (1993) has defined the process of downsizing as a deliberate organizational design carried out in order to reduce the work force which in turn is focused on improving the performance of the organization. Downsizing is also defined as a positive and purposive strategy. According to Cameron (1994) it is a set of organizational activities undertaken by management in order to improve organizational efficiency, employee productivity and overall organizational competitiveness. Hence downsizing comes under the category of those management tools targeted for achieving 
desired change, almost similar and synonym to "right sizing" and "reengineering." (Cameron, 1994)

Recent studies carried out in the USA have shown that more than 85 per cent of Fortune 500 companies have undergone downsizing during the past five years and another 100 per cent are planning to do so in the next five years (Buch, 1992). Between 1987 and 1991, a number of smaller firms planned to lay off around one million employees in order to streamline their operations and reduce hierarchical layers (Heenan, 2007).

\subsection{Impact of Downsizing on Employee Attitude}

Many research studies on downsizing have reported that the process of downsizing has major implications for the human resource of any organization. Not only does it affect the psychological bond between employees and management, it also gives rise to severe stress and strain among the employees in an organization. Hence it is critical for the top and the human resource management to not only consider performance of the employees but also try to understand their feelings after the downsizing and their remaining work life (Edwards, 2005).

Downsizing in organizations hence has become a stress-inducing factor that severely affects the survivors' attitudes and behaviors at work place (Brockner, 1988). In order to reduce the level of increasing stress, it is important for the management to develop an interpersonal relation with the employees to help them overcome this phase (Gilmore and Hirshorn, 1984; Sutton 1987).

Downsizing has also resulted in reduced morale and trust of survivors for the organization. Thus, although survivors who are people mainly responsible to revitalize the organization and provide customer satisfaction (Henkoff, 1994), they tend to have lesser commitment towards the organization, behaving like out sourced contractors, and are no longer committed to the overall welfare of the organization ( Cascio, 1993; Luthans and Sommer, 1999; Wagar, 1998).

The results of downsizing have affected the attitude of the employees to a great extent. This increased workload is also a reason for the increased frustration among the survivors (Kreisman, 2002). The survivors have experienced feelings of guilt, depression, resentment, betrayal, and anger (Brockner et al., 1992; Cameron, Freeman and Mishra, 1993; Noer, 1993).

One harmful outcome of downsizing has been a decrease in survivor loyalty, or a decline in survivor levels of organizational commitment. Management scholars have tracked this decline (Cascio, 1993; Noer, 1993) noting that the traditional relationship between employer and employee has been cut off.

Organizational commitment describes a particularly important facet of the employee's relationship with not only the management but also with the organization, specifically, the level of organizational citizenship and involvement (Meyer \& Allen, 1997; Mowday, 
Porter \& Steers, 1982). O'Reilly and his colleagues (O'Reilly \& Chatman, 1986; O'Reilly) suggested that commitment reflected the psychological ties between an employee and the organization. The survivors in the organization usually do not give long-term commitments because they wait for new opportunities to come from the market so that they switch from their existing organization. For these employees their personal benefits become their first priority rather than the organizational goals. (Campbell, Worrall, \& Cooper, 2000)

A research study carried out to explore the reactions of survivors in downsized organizations showed that job insecurity, financial problems and detachment to the job itself have the greatest negative influence on employee behavior (Kumar, 2006). Many research reports indicate that most of the survivors become self-absorbed, less creative and develop a more risk aversive attitude. This in turn has led to an approach me-first in organizations which have gone through downsizing (Brockner, 1988; Cascio, 1993; Tomasko, 1990; Luthans and Sommer, 1999).

During layoffs and downsizing, turnover among survivors also increases, especially among the top performers (Dunford et al, 1998; Meyer and Allen, 1997) The various reasons for increased turnover rate can be either due to downsizing or another important cause can be that survivors who are now suffer from job insecurity and hence starts looking around for new job opportunities in the market (Kamery, 2005)

But in other cases, turnover can be low as well because of few job opportunities in the market which restrict the employee to stay in that organization despite of high workloads and undesired pressures. (Corporate Downsizing)

\subsection{Impact of Downsizing on Employee and Organizational Performance}

Another crucial implication of downsizing besides its impact on employee attitude is its effects on the employee performance. Cascio (1993) pointed out that not only does downsizing fails to generate the expected outcomes in terms of employee productivity but it also negatively influences the stock prices of companies which have been downsized. He studied that although the stock prices in the S \& P's 500 stock index increased on the day of the announcement but starts sliding down afterwards. Similarly, Worrell, Davidson and Sharma (1991) also indicated in their studies that most of the investors reacted negatively to downsizing announcements.

On the other hand, some researchers favored downsizing since it does have some positive outcomes. According to Bowman and Singh (1993), when downsizing is followed by significant organizational changes, it results in a positive impact on the employee's performance. In an empirical study, it was revealed that companies which downsized white-collar workers showed a significant improvement in performance two years after the layoffs (Krishnan, 1998)

During downsizing period, it is implicit that the employees understand and agree with the reasons as provided by the management as legitimate. If the survivors do not believe 
the management, their commitment to the organization may get negatively influenced. Also if the survivors are getting personal benefits like increased packages or promotions or job enrichment, then their reaction to the whole process of downsizing will be more positive (Johnson, 2000). Inspite of an overall negative feeling generated by layoffs, there will still be survivors who may benefit because of the increased job challenge, or enhanced visibility. Distributive fairness theory lead the survivors towards a believe that if their job tenure is reduced in future, they would also be getting adequate compensation from the management (Bacal, 2008). Also, if the employees believed that downsizing was being carried out to save the company, negative impact on the survivors may be reduced (Folger, 1986; Folger \& Greenberg, 1985; Folger \& Konovsky, 1989).

Bleuel (2001) reports that instead of revitalising the organisation, downsizing has given rise to a new phenomenon called "the cycle of failure". This cycle involves adverse consequences starting with employee dissatisfaction and leading towards organizational in efficiency and decreased profitability.

For several years, there has been a strong tendency to adopt a downsizing strategy to deal with economic pressures in the environment. Once seen as a short-term measure, downsizing has become the way to increase profitability. Of course, there are many anticipated benefits of downsizing in terms of the economic level and increased operational efficiency of the organization. However, the hidden costs of this strategy are enormous and, more often than not, underestimated. In fact, they often eliminate all of the anticipated benefits. It has often been noted that employee uncertainty and fear can paralyze operations and lead to a significant decline in trust and motivation, affecting company's overall productivity (Dupuls, Boucher \& Clavel, 1996). While concentrating more on the leaving staff, the managers often overlook the importance of the survivors as they assume that the relief of not losing one's job will overshadow any negative feelings employees have about the downsizing process (Kreisman, 2002). It is a common understanding that the impact of downsizing will be pervasive across the entire hierarchy of an organization. However in traditional production and service organizations, a gap may exist between employees and management (Schein, 1985).

A study (Luthan et al, 1999) done in the health organizations shows that there will be significant differences in the decline between manager and front-line employee perceptions of job attitudes during the time of downsizing intervention. In addition, this study proposes that there will be significant differences between managers and front-line employees in their reactions to downsizing. This might be due to the fact that managers have been the more frequent targets for staff reductions in recent downsizing activities. Or it may be that their closer position to the decision making that influences reduction decisions may cause them to be more aware and accepting of who gets cut. Hence attitudes would differ based on whether the individual was a manager or front-line employee.

Companies that focus on striving to increase the bottom line by reducing their personnel must take into account the cost of employee discontent and must strive to manage any downsizing practices to ensure the continued support, loyalty and productivity of remaining employees. Management should respect the opinions, emotions and thoughts 
of an organization's most valuable asset-its people (Corporate downsizing).

\section{Findings}

In-depth interviews with the HRD revealed why despite various negative impacts of downsizing on survivors, HBL continue to focus on layoffs and downsizing. An analysis of the interviews showed that the need for downsizing at HBL arose mainly due to three reasons namely privatization, lean structuring, and cost reduction.

This process of downsizing has been conducted among all the departments of HBL. Most of the layoffs had been made from the non-clerical and clerical staff. It was followed by reduction in the officers (lower-level managers) and then executives (middle-level managers). According to Human Resource personnel, downsizing at HBL has resulted in improved performance and annual profits. The targets of downsizing as set by the organization have been achieved in term of low costs, higher profits for the bank and increased employee efficiency. The financial statements of HBL have shown increased profits after the process of downsizing was completed which indicates good performance.

The HR managers at HBL believe that the downsizing has improved the performance which is mainly due to the fact that employees who are left behind are working better because they are under pressure as they believe that if they do not deliver well they will be fired as well. The performance is gauged by looking at the profit and loss statement of bank which shows profits for the bank also because the cost that the bank was incurring for salaries is now being cut by at least $30 \%$. The absenteeism rate has also been controlled as strict rules regarding the attendance of the employees have been introduced in employee performance appraisal. Specific disciplinary regulations have also been introduced to address absenteeism.

\subsection{Questionnaire Data}

The sample of 200 has been divided into two groups, namely executives and officers. Questionnaires were distributed among 27 executives and 155 officers. The response rate was $90 \%$ among officers with 155 of them filling up the questionnaires while only $45 \%$ ( 15 only) of the officers responded. Since the trends were quite different among the two management levels, the analysis is based taking into consideration the middle (executives) and the lower level management (officers).

\subsubsection{Impact of Downsizing on Employee Performance}

An in-depth analysis of data showed that the continuous process of downsizing at HBL has surprisingly not negatively affected the performance of the survivors. This impact was measured on a numerical scale of 1-5 consisting of two items. Both the executives and the officers believed that both overall and individual performance have improved over the years. However, the results of the middle level employees showed slightly higher mean score as compared to that of the lower level managers for the positive impact on overall organizational and employee performance as indicated in the following tables. 
Table 3.2.1a Overall Job Effectiveness

\begin{tabular}{|l|l|}
\hline OVERALL JOB EFFECTIVENESS & MEAN SCORE VALUE \\
\hline Middle level Managers & 4.7 \\
\hline Lower level Managers & 4.3 \\
\hline
\end{tabular}

Table 3.2.1b Impact on Individual Performance

\begin{tabular}{|l|l|}
\hline Impact on Individual performance & MEAN SCORE VALUE \\
\hline Middle level Managers & 4.5 \\
\hline Lower level Managers & 3.8 \\
\hline
\end{tabular}

\subsubsection{Job Security}

Job insecurity consisted of two dimensions: the perceived threat of job loss and a sense of powerlessness to counteract the threat (Greenhalgh and Rosenblatt 1984). The perceived threat of job loss was measured with two items modified from the Job Insecurity Scale developed by Jick (1979). These items assessed the degree of worry about one's job and the level of confidence that the department would be a steady place of employment. The mean score values on a scale of 5 were 4.2 and 4.8 respectively for middle and lower level managers showing a high degree of worry for job security among the survivors irrespective of their management hierarchy. The respondents in both the middle and lower level expressed low confidence in job stability as indicated by a below average mean score rating of 2.3 and 2.1. Sense of powerlessness was assessed with a single item. The response categories ranged from 5 (great influence) to 1 (no influence at all). This parameter showed how secure people feel about their jobs as they are through the process of downsizing. A mean score value of 1.99 indicated clearly the survivors in the lower level had no influence at all and suffered from a huge sense of powerlessness while results for middle managers showed a different picture with higher mean score of 3.2 indicating a greater influence.

\subsubsection{Organizational Commitment and Citizenship}

Both the middle and lower level survivors had a low level of affective organizational commitment However mean score values for middle level were comparatively higher than the lower level officers. An aggregate mean score was calculated as shown in the following table to measure the organizational commitment.

Table 3.2.3a Organizational Commitment Combined

\begin{tabular}{|l|l|}
\hline $\begin{array}{l}\text { ORGANIZATIONAL COMMITMENT \& } \\
\text { CITIZENSHIP }\end{array}$ & AGGREGATE MEAN SCORE VALUES \\
\hline MIDDLE LEVEL MANAGERS & 3.02 \\
\hline LOWER LEVEL MANAGERS & 2.2 \\
\hline
\end{tabular}


Organizational commitment in the long-term was also measured using a three itemed Likert scale. These items assessed advancement opportunities, availability of well defined career paths and outlook for future plans with the organization. The analysis of the middle and lower level survivors showed difference in their long-term commitment towards the organization.

Table 3.2.3b Long-term Commitmnet - Middle Managers

\begin{tabular}{|l|l|}
\hline Long Term Goals & MEAN SCORE VALUES \\
MIDDLE MANAGERS & \\
\hline ADVANCEMENT OPPORTUNITIES & 3.6 \\
\hline WELL DEFINED CAREER PATH & 4.2 \\
\hline NARROW FUTURE PLANS & 4.0 \\
\hline
\end{tabular}

Table 3.2.3c - Long-term Commitmnet - Lower Managers

\begin{tabular}{|l|l|}
\hline Long Term Goals & MEAN SCORE VALUES \\
LOWER LEVEL & \\
\hline ADVANCEMENT OPPORTUNITIES & 2.8 \\
\hline WELL DEFINED CAREER PATH & 1.8 \\
\hline FUTURE PLANS & 2.5 \\
\hline
\end{tabular}

\subsubsection{Employee Morale}

The Likert Scale to measure organizational morale consisted of four items designed to reflect morale in terms of enthusiasm for the organization, dedication, encouragement and job satisfaction. The difference among the responses from the middle management was quite different from those of the lower management on all these dimensions. An average of all the mean scores was calculated to obtain a single measure for employee morale. This measured to be above average with a score of 3.95 for the middle managers while the average value for morale among the lower level survivors was below average with a measure of 2.33 on a scale of 5

Table 3.2.4- Employee morale

\begin{tabular}{|l|l|}
\hline EMPLOYEE MORALE & AGGREGATE MEAN SCORE \\
\hline MIDDLE LEVEL MANAGERS & 3.95 \\
\hline LOWER LEVEL MANAGERS & 2.33 \\
\hline
\end{tabular}




\subsubsection{Absenteeism}

Absenteeism among the employees at HBL was not very high. Only $30 \%$ of the officers availed their sick and annual leaves while this percentage was even lower for the executives with only $15 \%$ availing their sick and annual leaves. The qualitative analysis from the in-depth interviews attributed low absenteeism in spite of low morale among the officers due to job insecurity.

\section{Conclusion and Recommendations}

The study results indicated that some difference in attitude was measured based on whether the individual was an executive or an officer. In terms of collective-oriented attitudes-commitment and employee performance-there were significant differences by job level. Organizational commitment for the middle managers, although was slightly above average (mean score 3.02) but it was higher than that of the lower level managers (mean score 2.2). Employee performance, however, showed a positive change with an above average mean score values for both middle managers (4.7) and lower level (4.3) managers. This could be attributed to increased threat of job security leading towards improved performance.

Similarly, one-to-one type attitudes-job security, employee morale and long-term career advancement plans-also showed slight differences in attitude across the two management levels. Almost all the survivors felt insecure about their jobs and find their confidence for a steady job quite low with mean score values of 2.3 and 2.1 for middle and lower management levels. Employee morale among the middle managers indicated higher values for the middle management (mean score 3.9) as compared to a below average value for the lower level employees (mean score 2.3). The lower level managers also find themselves having reduced long-term plans (mean score 2.8) and well defined career paths (mean score 1.8). However, this lack of long-term career planning was not evident among the middle managers with higher mean scores of 3.6 and 4.2 respectively for the same measures.

As a whole, the performance of employees after downsizing has improved. This may be due to the pressure that employees now face regarding losing their jobs. Increased profits are also a result of the reduced costs because of a cut in the number of employees. Conclusively, it can be said that Habib Bank Limited (HBL) has achieved the objectives for which it adopted the policy of downsizing. However, it has raised a feeling of insecurity among the employees, lowered organization commitment and morale, especially among the lower level managers.

This study provides an insight into several implications that may help improve the practice of downsizing. The resulted negative attitudes may be a leading indicator of organizational inefficiency or human resource management problems. An active communication and interactive policy can help reduce job insecurity. This will also in turn increase employee morale and commitment towards the organization, especially among the lower level managers. 
The interview findings showed that career counseling and learning department was established after the downsizing process. However the questionnaire findings showed low long-term planning among the lower management. This indicates a need to revise the policies of this department which apparently has only catered to the needs of the middle management. Downsizing is a decision that organizations need to consider carefully and not enter into lightly. There are significant tradeoffs to consider hence it is recommended that future research investigating a broader range of outcome variables should be carried out. In addition to job insecurity and organizational commitment, hard criteria measures of performance, productivity, turnover, and absenteeism could be examined. 


\section{References}

Bacal, R. (2008) 'Leading Those That Remain', http://www.work911.com/articles/downsizing.htm

Bacal, R. (2008) 'Downsizing-The Long Term Effects', www.work911.com/articles/downsizinglongterm.htm

Bleuel, W. (2001), Curbing the "cycle of failure", www.scantronsurveys.com/

Brockner, J., Grover, S. L. and Blonder, M. D. (1988), "Predictors of survivors' job involvement following layoffs: a field study", Journal of Applied Psychology, Vol. 73 No. 3, pp. 436-42.

Brockner, J., Tyler, T. R. and Cooper-Schneider, R. (1992), "The influence of prior commitment to an institution on reactions to perceived unfairness: the higher they are, the harder they fall", Administrative Science Quarterly, Vol. 37, pp. 241-61.

Bowman, E. H, Singh, H. (1993), 'Corporate restructuring: Reconfiguring the firm', Strategic Management Journal, Vol. 14, No. 1, pp. 5-14.

Buch, K. (1992) 'How does downsizing affect employee involvement?' Journal for Quality and Participation.

Cameron, K. (1994) 'Investigating organizational downsizing--fundamental issues' Human Resources Management, pp183-188.

Campbell, F., Worrall, L., \& Cooper, C. (2000). The Psychological Effects of Downsizing and Privatization. University of Wolverhampton.

Cascio, W. F. (1993), "Downsizing: what do we know? What have we learned?" Academy of Management Executive, Vol. 7 No. 1, pp. 95-104.

Corporate Downsizing, www.allsands.com/money/career/corporatedownsi_zro_gn.htm

Droege, S. B. (n.d.). Downsizing and Rightsizing. Retrieved January 12, 2009, from Encyclopedia of Management: http://www.enotes.com/managementencyclopedia/downsizing-rightsizing

Dunford, R., Bramble, T. and Littler, C. R. (1998), "Gain and pain: the effects of Australian public sector restructuring", Public Productivity and Management Review, Vol. 21 No. 4, pp. 386-402.

Duplus, L., \& Boucher, S., \& Clavel, L. 1996. Downsizing its effects on survivors.Monogrph.4, http://www.psccfp.gc.ca/publications/monogra/mono4 e.htm

Journal of Independent Studies and Research - MSSE

Volume 8

Number 1

January 2010 168 
Edwards, J. C. (2005, January 1) 'Perceived Breach of Contract for One's Own Layoff v s. $\quad S \circ \mathrm{m}$ e $\mathrm{n}$ e $\quad$ E I s e 's $\mathrm{s}$ a y of $\mathrm{f}^{\prime}$, http://www.allbusiness.com/buying_exiting_businesses/3503620-1.html

Folger, R. and Konovsky, M. A. (1989) 'Effects of procedural and distributive justice on reactions to pay raise decisions', Academy of Management Journal, Vol. 32 No. 1, pp. 115-30.

Habib Bank Ltd. http://www.habibbankltd.com/about-us

Heenan, D. A. (2007). 'The Downside of Downsizing'. Emarald Backfiles , pp. 18-23. Henkoff, R. (1994), 'Getting beyond downsizing', Fortune, pp. 30-4.

Jaewon, L. J., \& Corbett, M. (2006), 'The impact of downsizing on employees' affective commitment', Journal of Managerial Psychology.

Johnson, J. (2000) The impact of downsizing and restructuring on organization competitiveness, MSB University Press. Ltd.

Kamery, R. H. (2005), The effects of the trend to increase profits and stock prices:Downsizing in 1990, Nova Southeastern University.

Karen Bandera, S. C. (1998), Report of an oversight special duty: Downsizing in the Federal Government.

Kozlowski, S. W., Chao, J., Smith, G., \& Hedlund, J. (1993), 'Organizational downsizing: Strategies, interventions, and research implications', International Review of Industrial and Organizational Psychology, pp.263-332.

Kreisman, B. J. (2002), 'Insights Into Employee Motivation', Commitment and Retention.

Krishnan, H. A. (1998, October), 'Effects of top management team change on performance i $n \quad d o w n s i z$ d U S c o m p a n e s', http://findarticles.com/p/articles/mi_hb3265/is_/ai_n28721746

Kumar, D. (2006, January 8), 'Impact of Downsizing on 'Retainers' Behaviour', www.indianmba.com/Faculty_Column/FC237/fc237.html

Leana, C. a. (1988) 'When Mergers Force Layoffs: Some Lessons about Managing the Human Resource Problems', Human Resources Planning, pp. 123-140.

Luthans, B. C; \& Sommer, S. (1999), 'The Impact of Downsizing on Workplace Attitudes: Differing Reactions of Managers and Staff in a Health Organziation,' Group Organization Management 1999; http://gom.sagepub.com/cgi/content/abstract/24/1/46

Meyer, J.P., Allen, N.J. and Smith, C.A. (1993), 'Commitment to organizations and 
occupations: extension and test of a three-component conceptualization', Journal of Applied Psychology, Vol. 78, No. 4, pp. 538-51.

Meyer, J.P. and Allen, N.J. (1997), 'Commitment in the Workplace: Theory, Research, and Application', Sage Publications, London.

Makawatsakul, N. and Kleiner, B. H. (2003), 'The Effect of Downsizing on Morale and Attrition', Management Research News, Vol. 26, No. 2, 3 \& 4.

Moravec, M., Knowdell, R., \& Branstead, E. (1994) 'Mistakes to avoid during downsizing,' HR Focus, Vol. 71, p. 7.

Noer, D. (1993), Healing the Wounds: Overcoming the Trauma of Layoffs and Revitalizing Downsizing Organizations, Jossey-Bass, San Francisco, CA, p. 248.

O'Reilly, C. III \& Chatman, J. (1986) 'Organizational commitment and psychological attachment: The effects of compliance, identification, and internalization on personal behavior,' Journal of Applied Psychology, Vol. 71: pp. 492-499.

Schein, E. H. (1985) Organizational culture and leadership. San Francisco: JosseyBass.

Sutton, R. and D'Aunno, T. (1989) 'Decreasing Organizational Size: Untangling the Effects of Money and People', Academy of Management Review, Vol. 14, No. 2, pp. 194-212.

Tomasko, Robert, (1990) 'Downsizing: Reshaping the Corporation for the Future,' American Management Association.

Wagar, T. H. (1998) 'Exploring the consequences of workforce reduction', Canadian Journal of Administration Sciences, Vol. 15, No. 4, pp. 300-9. 